\title{
CHILDHOOD HOUSING AND ADULT EARNINGS: A BETWEEN-SIBLINGS ANALYSIS OF HOUSING VOUCHERS AND PUBLIC HOUSING
}

\author{
by \\ Fredrik Andersson \\ Office of the Comptroller of the Currency
}

John C. Haltiwanger

University of Maryland and NBER

Mark J. Kutzbach

U.S. Census Bureau

Giordano Palloni

University of Maryland \& U.S. Census Bureau

Henry O. Pollakowski

Harvard University

Daniel H. Weinberg

U.S. Census Bureau

\section{CES 13-48 September, 2013}

The research program of the Center for Economic Studies (CES) produces a wide range of economic analyses to improve the statistical programs of the U.S. Census Bureau. Many of these analyses take the form of CES research papers. The papers have not undergone the review accorded Census Bureau publications and no endorsement should be inferred. Any opinions and conclusions expressed herein are those of the author(s) and do not necessarily represent the views of the U.S. Census Bureau. All results have been reviewed to ensure that no confidential information is disclosed. Republication in whole or part must be cleared with the authors.

To obtain information about the series, see www.census.gov/ces or contact Fariha Kamal, Editor, Discussion Papers, U.S. Census Bureau, Center for Economic Studies 2K132B, 4600 Silver Hill Road, Washington, DC 20233, CES.Papers.List@census.gov. 


\begin{abstract}
Research on effects of living in voucher-assisted and public housing to date has largely focused on short-term outcomes, while data limitations and challenges of identification have been an obstacle to conclusive results. In contrast, this paper assesses effects of children's housing on their later employment and earnings, uses national longitudinal data, and makes use of withinhousehold variation to mitigate selection issues. We combine several national datasets on housing assistance, teenagers and their households, and the subsequent earnings and employment outcomes, such that we are able to follow1.8 million children aged 13-18 in 2000 in over 800,000 households within many different assisted and unassisted housing settings, controlling for neighborhood conditions, and examine their labor market outcomes for the 2008-2010 period. By focusing on within-family variation in subsidy treatment, we remove a substantial source of unobserved heterogeneity affecting both a child's selection into housing and their later outcomes. OLS estimates show a substantial negative effect of housing subsidies on earnings and employment outcomes. However, using within-household variation to control for selection issues attenuates these effects, and results in positive effects for some demographic groups. The large sample size allows us to study to what extent results vary by gender and race/ethnicity, and we find strong evidence of heterogeneous effects. Children in Black households who have lived in voucher-supported housing and public housing often benefit in terms of positive subsequent economic outcomes. Girls raised in Black households derive a considerable positive effect on later earnings from having lived in voucher-supported housing, and a somewhat lesser effect from having lived in public housing. Boys raised in Black households fare relatively worse than girls; in contrast, girls in White households tend to have relatively worse outcomes than boys.
\end{abstract}

\footnotetext{
Any opinions expressed herein are those of the authors and do not necessarily represent the views of the Office of the Comptroller of the Currency or the U.S. Census Bureau. All results have been reviewed to ensure that no confidential information is disclosed. This research is being supported by grant number 98082 from the "How Housing Matters" research program of the John D. and Catherine T. MacArthur Foundation. This research uses data from the Census Bureau's Longitudinal Employer Household Dynamics Program, which was partially supported by the following National Science Foundation Grants: SES-9978093, SES-0339191, and ITR-0427889; a National Institute on Aging Grant AG018854; and grants from the Alfred P. Sloan Foundation. The authors want to thank Emily Mytkowicz for her valuable research assistance and Daniel Hartley, Kristin McCue, and Erika McEntarfer for their comments on the preliminary draft.
} 


\section{Introduction}

Children's housing - through its impact on allocation of a household's budget, its implications for availability of and access to local employment opportunities for their parents, and its association with specific neighborhood conditions - may significantly affect their later life outcomes. In spite of the large public expenditure on assisted housing (in Fiscal Year 2011, the U.S. spent over $\$ 40$ billion - see Falk 2012), research on long-term impacts of children’s housing is scarce and hampered by data limitations. This paper helps remedy this gap by analyzing how children's housing affects their early adulthood employment and earnings using combined data on housing assistance, earnings, household structure, neighborhood and demographic characteristics. By matching these files at the person level, we are able to track millions of children into adulthood across a variety of settings of childhood housing: vouchersupported, public, and unassisted housing.

A number of potential factors related to the housing that children occupy may have opposing effects on subsequent labor market outcomes. For example, both voucher and public housing may have a positive effect related to the core motivation for their provision: these programs enable lower-income households to relax their time and financial resource budget constraints. This implies that, in principle, more time and financial resources can be devoted to the support of the children in the household. Viewed from this perspective, assisted housing may provide a boost to the resources available to the children in the household and therefore have a positive impact on subsequent labor market outcomes.

However, alternative factors potentially work in the opposite direction. Important to consider is whether the environment at home and in its neighborhood is conducive for youth to stay healthy and safe and have the opportunity to succeed academically. Here it is important to distinguish between voucher-supported housing and public housing, since an argument in favor of voucher housing is that more neighborhood choice is available. Previous research has investigated physical and mental health outcomes that using a voucher to move to a lowerpoverty neighborhood has on youth. This research has indicated a potential difference in the mental health outcomes that might to relate a youth's gender, with positive effects found for 
female youth moving to lower-poverty neighborhoods and worsened outcomes for a variety of indicators for male youth moving to lower-poverty neighborhoods (Sanbonmatsu et al., 2011).

Related to such effects are neighborhood effects. By neighborhood effects, we mean the crime, health, and peer group effects associated with a neighborhood, among others. Soon after its construction, high-rise public housing drew the criticism that its design isolated residents and lacked the "defensible space" necessary for a community to "self-police" (Newman, 1972). Our study focuses on the early 2000s, a transitional period with an abundance of both project-based public housing and a rising use of vouchers to obtain housing.

The datasets employed are crucial to the questions asked and the resulting research design. We begin by developing a frame of households and children from the internal version of the 2000 Decennial Census "short form" file. The short form data provides comprehensive coverage of teenagers and their households in 2000 with key demographic characteristics. Next, we use person identifiers developed at the Census Bureau to link the parents and children to an administrative data file of housing assistance recipients provided by the Department of Housing and Urban Development (HUD), known as HUD-PIC. ${ }^{1}$ The HUD file covers the years 1997 and forward, so we can identify each year a parent or child is in subsidized housing, and whether they were in public housing or received a housing voucher enabling them to live in private-sector housing. We also use the unique person identifiers to match children to a residence location in each year from 1999 to 2005, and add variables describing characteristics of the neighborhood. Last, we use the unique person identifiers to link the children in the sample to their earnings records for 2008-2010. ${ }^{2}$ The Census Bureau's Longitudinal Employer-Household Dynamics (LEHD) dataset provides earnings records for over 130 million workers each quarter from the mid-2000s onwards. ${ }^{3}$ These records provide a measure of labor market outcomes for children including total earnings and quarters of employment. The resulting sample size is sufficiently

\footnotetext{
${ }^{1}$ PIC refers to Public and Indian Housing Information Center. The data file contains an annual extract of recipients of voucher-supported housing and public housing, submitted by housing authorities and providers. For other research using the HUD-PIC extract file, see Lubell et al. (2003); Mills et al. (2006); Olsen et al. (2005); Shroder (2002); and Tatian and Snow (2005). We do not use the HUD-TRACS (Tenant Rental Assistance Certification System) since those data apply to project-based Section 8 subsidies.

${ }^{2}$ We recognize that 2008-2010 is a sluggish period for the national labor market, but our identification approaches are designed to exploit the cross-sectional variation. In future work we may consider whether the effects vary across the business cycle.

${ }^{3}$ For a description of the LEHD infrastructure files and public statistics, see Abowd et al. (2004).
} 
large to allow us to present results disaggregated by race and ethnicity (Hispanic origin) and gender.

Unobserved heterogeneity and the associated selection bias is a first-order challenge in estimating causal effects of housing. In particular, households who participate in public housing or housing voucher programs can be quite different from those who do not, and those who leave subsidized housing can be different from those who do not; these differences can exist along observable and unobservable dimensions that also impact labor market outcomes. For example, unobservable characteristics of parents may both increase the likelihood of children experiencing subsidized housing and affect the child directly, in ways that influence the child's later labor market outcomes. Unobservable parent characteristics may also affect the likelihood of living in voucher-supported housing as opposed to public housing. As a result, conditioning only on detailed observable characteristics, either by using Ordinary Least Squares regression or propensity score matching, is not sufficient to address the potential selection bias. This paper addresses this issue by taking advantage of the rich longitudinal nature of our data. Specifically, we use a household fixed-effects specification that exploits variation in voucher-supported housing and public housing participation across siblings over time within households. This allows us to isolate the effects of types of subsidized housing on labor market outcomes from the separate effect of other, observed and unobserved time invariant factors that are correlated with subsidized housing participation.

The next section provides background information on housing subsidies, followed by a section that reviews a selection of studies on the effects of living in different types of subsidized housing. Section 4 describes the data and section 5 the research design, hypotheses, and identification issues. Section 6 describes the sample and section 7 provides the empirical results. The last section provides concluding comments.

\section{Background: Housing Subsidies}

As of 2000, about 1.8 million American households lived in voucher-supported housing and about 1.3 million lived in public housing, made affordable by HUD subsidies. ${ }^{4}$ An even

\footnotetext{
${ }^{4}$ An additional 875,000 households lived in “old-style” Section 8 project-based HUD-subsidized housing, referred to as "New Construction or Substantial Rehabilitation." These households are smaller, with the majority not having children. Since our emphasis is on effects on children, we have chosen to limit our study to voucher housing and public housing. Also, in 2000 about 950,000 households lived in housing
} 
larger number were qualified in terms of income but were unable to participate. In recognition that the primary types of federally subsidized rental housing differ along important dimensions, this paper compares the effects of living in subsidized rental public housing and subsidized voucher housing. In 2000, a central year in our study, 45 percent of public housing households and 61 percent of voucher households included children (Table 1). We provide a description of the major federal housing assistance programs that we consider in Appendix A. Table A-1 presents summary statistics of the HUD administrative rental subsidized housing data for the two major programs that we consider.

HUD defines eligibility for its assistance programs based on family income as a percentage of Area Median Income (AMI), which adjusts for area income and for family size. Under most HUD programs, households pay 30 percent of their income for rent with HUD subsidizing the remainder to cover operating costs or up to a fixed local "Fair Market Rent". Actual program requirements vary by subsidy type, but generally require residents to earn less than 80 percent of AMI (low income), with additional requirements dictating the percentage of residents that must be "very low income" (at or below 50 percent of AMI) or "extremely low income" (at or below 30 percent of AMI).

\section{Literature Review}

\subsection{Comparability of studies}

There is a broad literature estimating the economic effects of housing subsidies, although studies of the long-run impacts on children are scarce. After a few introductory comments about the general literature, we will focus on the studies most relevant to our study -- those that attempt to deal with selection issues. In the broad literature, conclusions about the effects of subsidized housing vary considerably. In part, the mixed results are likely a reflection of different study designs -- many of the studies estimate the impact of moving from one type of subsidy to another. While certainly an interesting and policy relevant parameter, these studies are unable to answer how the different subsidy types compare to receiving no subsidy. Others that do compare 
subsidized households against non-subsidized households do not distinguish among different subsidy types and thus miss potentially important distinctions among the different programs. ${ }^{5}$

Studies that have been able to compare multiple subsidy types to private, unassisted households typically do so for a limited geographic area (typically a city or metropolitan area) and/or select samples and focus on short-term, rather than longer-term outcomes. ${ }^{6}$ One set of studies generally relies on conditional-on-observables identification strategies. Public housing residents differ in observable characteristics from others, often having characteristics typically associated with worse employment and educational outcomes. If these characteristics also make households more likely to reside in public housing, then the estimated effects of housing on outcomes are likely biased (for a general discussion, see Shroder, 2002).

\subsection{Identification challenges}

Some researchers have used instrumental variables (IVs) to identify the effect of housing on outcomes, generally making use of public administrative data to estimate the effects of public and assisted housing. In one such study, Currie and Yelowitz (2000) identified a regulation in housing assignment that requires an extra bedroom for households with two children of different gender, compared to those with two children of the same gender. They used the instrument of having opposite-gender children to estimate the effect of public housing on child outcomes. This bonus room improves the public housing offer and made income-eligible households 24 percent more likely to participate in public housing. Currie and Yelowitz used the Current Population Survey (CPS) to estimate the likelihood of living in public housing and the Census Public Use Microdata Sample (PUMS) to estimate the effect on outcomes. Although the PUMS sample is large, it does not include data on public housing participation. ${ }^{7}$ Currie and Yelowitz used a two-

\footnotetext{
${ }^{5}$ For example, Olsen et al. (2005) used longitudinal HUD administrative data from 1995 to 2002 combined with data from other sources and a large, nationwide random sample to assess the employment results of multiple types of assistance. The authors found that each type of housing assistance has substantial negative effects on labor earnings that are somewhat smaller for tenant-based housing vouchers than for project-based assistance.

${ }^{6}$ For example, Bania et al. (2003) compares welfare leavers who received Section 8 housing vouchers or project-based housing, with other welfare leavers. The study was limited to Cuyahoga County (Cleveland), Ohio, and followed residents from 1996 through 1997 using administrative data. They found no significant effect from the receipt of housing assistance, and no difference between voucher and project-based assistance recipients.

${ }^{7}$ Specific neighborhoods cannot be identified in the PUMS data, as the smallest area identified on the file must have at least 100,000 people.
} 
sample IV procedure, incorporating both CPS and PUMS, to estimate the effect of housing, and found that assisted housing reduces overcrowding and improves children's education.

Newman and Harkness (2000) also instrumented for participation in public housing, but used a much more aggregate-level instrument. With a sample of about 1,000 individuals from the Panel Study of Income Dynamics (PSID), they developed a county-level measure of public housing availability by regressing the number of assisted housing units per income-eligible family in each county on county characteristics, and used the regressions' residual for each county as the IV to estimate the effect of public housing on children's educational attainment. Newman and Harkness found no effect of assisted housing on children's education.

Absent an appropriate policy experiment (see below) or IV for housing participation, some researchers have used propensity score matching and other control variable-based methods to measure how outcomes differ among households in different public housing projects or programs. One notable example of this is Susin (2005), who used a rich set of controls from survey data to match households from public housing, Section 8 Housing Choice vouchers, and project-based subsidies with low-income non-recipient control households, and compared household earnings and participation in other subsidy programs. Susin used the Survey of Income and Program Participation to obtain a nationally representative sample of over 2,000 individuals. Susin acknowledged some potential biases; for example, households with permanently low incomes may be matched with those with temporarily low incomes. To avoid this, matches were made based on multiple periods or employment history, rather than on average earnings over one long period. Susin found that housing subsidies reduce incentives to work and reduce earnings, with no difference between voucher and project-based assistance recipients.

Recent work by Carlson et al. (2012a, 2012b) is relevant to our study given its focus on employment and mobility outcomes for those receiving housing vouchers. The authors relied on administrative records in two databases maintained by the State of Wisconsin combined with Census Bureau public use microdata. They drew a sample from the state's Client Assistance for Re-employment and Economic Support system, with 12,170 cases in the voucher group and 342,000 cases in the control group for up to 6 years after receipt of vouchers. Because the sample is from assistance data, both voucher recipients and control households received assistance of some sort. Using propensity score matching techniques, they found that 6 years after voucher 
receipt there is little effect on employment, but a negative effect on earnings that is largest in the years immediately following voucher receipt and lessens after that (Carlson et al. 2012a).

Additional work indicates that voucher receipt resulted in both short- and long-term mobility and had little to no effect on four measures of neighborhood quality in the short term, but small longterm improvements in all quality indicators (Carlson et al. 2012b).

\subsection{Experimental and quasi-experimental studies}

A highly regarded approach to estimate an unbiased effect is to use an experiment or, failing that, quasi-experimental techniques. Some studies have taken advantage of public initiatives that arguably resulted in unbiased sample selection. One such program is the Gautreaux project, ending in 1998, in which the Chicago Housing Authority (CHA) distributed Section 8 housing vouchers to 7,100 African-American families on welfare. The vouchers were to be used to rent private market apartment units in either suburban or urban locations chosen at random by the CHA. Using the Gautreaux project's ready-made sample, Rosenbaum (1995) surveyed 332 adults, conducting detailed interviews with another 95, and found that adult suburban movers experienced higher employment but no different wages or hours worked than their counterparts.

Inspired in part by the Gautreaux project, HUD’s Moving to Opportunity (MTO) project randomly assigned 4,600 households living in public housing projects in five cities to receive Section 8 housing vouchers for use in areas with a poverty rate below 10 percent. The MTO program has challenged the findings from the Gautreaux project, that neighborhood mobility improves some employment outcomes. Despite the fact that some voucher recipients had improved neighborhood conditions, the impact evaluation (U.S. Department of Housing and Urban Development, 2011) indicates that there was no significant effect on employment or earnings outcomes for adults or their grown children (as reported by the parents).

The Welfare-to-Work Voucher Program provided housing vouchers to 50,000 families receiving or eligible to receive welfare. Mills et al. (2006) used an 8,371-household sample from seven public housing agencies to evaluate the differences in outcomes between those receiving vouchers and those that do not. The authors found that vouchers somewhat improve the neighborhoods in which extremely low-income families live, but that over a 31/2- year study period, vouchers had no impact on employment or earnings. 
Jacob (2004) made use of the schedule of public housing demolitions in Chicago. Because housing authorities demolished housing projects in stages for administrative reasons, the schedule of building closures forced some households to vacate their residence in exchange for a Section 8 housing voucher, while others could remain in public housing for a longer period. Jacob used administrative data from the Chicago Public Schools on places of residence and test scores for 94,000 students, matched with public housing addresses. Jacob found that children leaving public housing fared no better or worse than their peers did, possibly because they relocate to similar neighborhoods.

Jacob and Ludwig (2012) made use of a Chicago Housing Authority program that randomly assigned households to a position on the waiting list. Of the 82,607 households who applied for Section 8 vouchers between 1997 and 2003, they focused on the 90 percent of applicants living in private-market housing. Thus, their study differs from the MTO experiment, which instead focused on applicants already living in public housing. They found that vouchers reduce quarterly employment rates and earnings and increase participation in the Temporary Assistance for Needy Families program. Additionally they found no evidence that neighborhood quality has a significant impact on employment outcomes.

Oreopoulos (2003) used another quasi-experiment, a household's random draw of an initial assignment from among the available set of housing units in Toronto, to estimate neighborhood effects on children who grow up in a variety of locations. Oreopoulos used Canadian tax data from the Intergenerational Income Database to measure child earnings and match them to parents' places of residence, which they then matched to housing projects. With a sample size of about 9,000, Oreopoulos found no effect of neighborhood conditions on eventual earnings or welfare participation.

\section{Research Design, Hypotheses, and Identification Issues}

Our primary goal is to identify the causal effect of living in subsidized rental housing as a teenager on eventual labor market success. To do so, we begin by specifying a linear, constant effects regression model for the total earnings from 2008 to 2010, $y$, of teenager $i$ as

$$
y_{i f}=\alpha+\beta^{\prime} H_{i}+\phi^{\prime} X_{i f}+\gamma^{\prime} Z_{i f}+\epsilon_{i f}
$$


where $f$ indexes the household including child $i$ in the year $2000 .^{8}$ The outcomes measure adult outcomes while the explanatory variables pertain to the teen's unchanging characteristics or teen years; $\alpha$ is an intercept. The variables of interest, $H_{i}$, are dummy variables that measure participation in subsidized housing (public housing or housing voucher) as a teenager. For now, consider just a single treatment indicator. The vector $X_{i f}$ includes other unchanging child and household control variables measured in 2000. The vector $Z_{i f}$ contains a set of unobserved, timeconstant, characteristics that may be related to $y_{i f}$. Lastly, $\epsilon_{i f}$ is an independent error term.

Further, suppose that $Z_{\text {if }}$ can be partitioned into two separate parts, $Z_{i f}=Z_{i}, Z_{f}$. Similarly, $\gamma^{\prime}=\left[\gamma_{i}^{\prime}, \gamma_{f}^{\prime}\right]$. The first factor, $\mathrm{Z}_{f}$ is the composite of all observed and unobserved time-invariant characteristics for each household $f$ that are common to all children $i \in f$ and $\gamma_{f}$ is the associated effect. ${ }^{9}$ The remaining factor, $Z_{\tilde{i}}$, contains other characteristics that vary by child, such as variation in household income during childhood, neighborhood characteristics, birth order or disability, that may also be related to entry into HUD assistance and to later outcomes.

Consider estimating equation (1) using Ordinary Least Squares (OLS) and, thereby, omitting the unobserved characteristics in $Z_{\text {if }}$. The estimated coefficient $\hat{\beta}_{\text {oLs }}$ will include both the true effect of subsidized housing participation and a term arising from omitted variable bias. The sign of the bias will depend on the effect of the omitted, household-specific characteristics on earnings $(\gamma)$ and the covariance between participation in subsidized housing and the omitted characteristics. For example, if households with unobserved characteristics that tend to depress child outcomes are also more likely to enter public housing, then $\hat{\beta}_{\text {oLS }}$ will be biased downward. Thus, a finding that subsidized housing depresses child outcomes may be spurious unless the specification controls for these potential biases.

To account for the possibility that ignoring unobserved, time-unchanging characteristics correlated with both housing participation and labor market outcomes will bias naïve OLS

\footnotetext{
${ }^{8}$ A future version of the paper will look also at the number of quarters worked over the period.

${ }^{9}$ One might also consider $Z_{h}$, a set of variables relating to whether a household has one or both parents who ever reside in assisted housing themselves. Those households with a parent ever in HUD from 2000 to 2010 would have characteristics $Z_{h=1}$, while those never residing in HUD would have characteristics $Z_{h=0}$. If all households $Z_{h=1}$, have some common unobserved characteristics that are associated with selection into participation, and may also be related to children's outcomes. $\gamma_{h}$ would give the effect on earnings of any time-constant, unobservable characteristics common to all teenagers in the ever-resident sample $\left(Z_{h}\right)$. Thus, conditioning on whether a teenager's household reference person (or spouse) is ever observed in subsidized housing may also provide an unbiased estimate.
} 
estimates, we propose an alternative identification strategy. If unobserved heterogeneity across households that take up subsidized housing explains the bias in the OLS estimate of $\beta$, and these unobserved differences are important determinants of labor market outcomes, then conditioning on household will yield unbiased estimates of the true effect.

To that end, we estimate $\beta$ using household fixed-effects regressions that rely on variation across siblings within the same household. Griliches (1979) provides a summary of the early literature that makes use of sibling fixed effects and points out a number of potential issues. Recent studies include (1) Royer (2009) who used over 3,000 twin pairs and twin fixed effects to estimate the effect of birth weight on long-term outcomes, (2) Currie and Walker (2011), who used mother fixed effects to estimate the impact of the introduction of EZ-Pass in New Jersey and Pennsylvania on infant health outcomes, and (3) Currie et al. (2010), who employed sibling fixed effects to identify the relationship between early childhood health problems and outcomes in early adulthood. An especially relevant siblings study is Aaronson (1998), who estimated the effect of neighborhood on children's educational outcomes. Aaronson used the PSID to examine over 2,000 individuals in over 700 families and measures differences in exposure to high poverty neighborhoods across siblings. He found negative effects on high school graduation with and without the household fixed effects. He also evaluated the validity of using across-sibling variation by examining whether moves into or out of high-poverty neighborhoods co-vary with other household characteristics, such as parents' income.

Our approach builds on these previous studies but is unique in a number of respects. For one, our focus is on longer-term labor market outcomes of the impact of living in subsidized housing when young. For another, we use longitudinal information about households to exploit differences across siblings in the exposure to subsidized housing. In our study, the household fixed-effects estimates control for time-constant, unobserved household-level heterogeneity $\left(\mathrm{Z}_{f}\right)$. The household fixed-effects (HFE) regression estimates the effect of subsidized housing participation on labor market outcomes using only variation in housing participation and outcomes across teenagers within the same household. In practice, we subtract out the household mean of each dependent and independent variable from each observation within a household. Therefore, HFE only uses observations from household $f$ to help identify $\hat{\beta}_{H F E}$ if there are at least two teenagers $i$ and $j$ aged 13-18 in the household in 2000 where $H_{i} \neq H_{j}$. For example, consider a household in the year 2000 with a 17 year-old and a 14 year-old that does not enter 
HUD-subsidized housing until 2003. The older sibling would have $H_{i}=0$ and the younger sibling would have $H_{i}=1$. The effects of observed characteristics common among all children in a household are not separately identified, but instead subsumed in $\gamma_{f_{0}}$ so only a subset of $X_{i f}$ remains. The HFE model is written as:

$$
y_{i f}=\alpha+\beta_{H F E}{ }^{\prime} H_{i}+\phi^{\prime} X_{i}+\gamma_{f}+\gamma^{\prime} Z_{i}+\epsilon_{i f}
$$

where $\gamma_{f}$ gives the fixed effect for all children in household $f$ and where all children are in a household with at least two children. In practice, $H_{i}$ is a vector containing measures of participation in both public housing and housing voucher programs as a teenager, $X_{i}$ contains an indicator for whether the teenager is male, a set of age dummies, and, in some specifications, an interaction between whether the teenager is male and the race/ethnicity of the household. We also interact each of the subsidized housing measures with whether the teenager is male to allow for heterogeneous effects by teenager gender, and we estimate separate regressions for each race/ethnicity to allow all coefficients to vary. We estimate both a "dummy" version where the "treatment" $H$ is a set of two binary indicator variables for whether an individual resided in each type of subsidized housing as a teenager and a "dose" version where treatment is the number of years an individual resided in each type of subsidized housing between ages 13 and 18.

The HFE estimation provides an unbiased estimate of the effect of teenage subsidized housing residence on labor market outcomes under much less stringent conditions than a typical conditional on observables approach (including propensity-score matching approaches, in which identification also hinges on controlling for all relevant observables that determines selection and impact outcomes). There are, however, two types of characteristics contained in the childspecific factor, $Z_{\tilde{i}}$, that could lead to bias in $\hat{\beta}_{H F E}$. First, any household-specific and time-varying characteristic that is correlated with both subsidized housing residence and labor market outcomes will lead to bias. For example, if families enter subsidized housing in response to negative economic shocks and under the assumption that these are also harmful to the subsequent labor market outcomes of the child, $\hat{\beta}_{H F E}$ would be a downward-biased estimate of the true effect. ${ }^{10}$ In fact, HUD strongly prefers and in some cases requires that program households be

\footnotetext{
${ }^{10}$ Job loss by a household member is an example of an economic shock, though it is unlikely that housing subsidies are responsive to transitory events as the waiting lists are typically substantial. Another plausible scenario given eligibility requirements imposed by HUD is that households are more likely to be
} 
below a certain income threshold. This suggests that if any bias from unobserved, time-changing heterogeneity is present, this bias is likely to be negative. To address this possibility, we also consider HFE specifications where we control for the parents' earnings while the teenager is between 13 and 18. This variable will capture differences in the household earnings across siblings that have different subsidized housing experiences.

A second potentially confounding unobserved characteristic is any within-household, teenager-level heterogeneity that is correlated with both labor market outcomes and subsidized housing participation. In this case, the direction of the potential bias is less clear. However, we control for gender differences and it is rather implausible that this type of bias would contaminate the HFE estimates. The decision to move into subsidized housing is made at the household level. In effect, for this to be a concern, households would have to be making housing decisions in response to the characteristics of one teen but not the characteristics of the other teenage household members.

\section{Description of the Data}

\subsection{Siblings sample frame}

The data we will use links person- and household-level records from the 2000 Decennial Census with administrative records data. Specifically, we use the responses from the 2000 Census to construct a frame of over 1.8 million youth aged 13-18 and their households. Because our focus is on employment outcomes from 2008 to 2010, we require that children are at least age 13 in 2000, meaning they will be at least 21 by 2008 and are likely to be entering the labor force even if they attained some higher education. We cap the sample at age 18 and require that in 2000 the child was in a household with their parent(s). Including older youths would undermine the focus of the paper and our identification approach relies on the assumption of parents making housing decisions for children.

As our research design intends to examine the effect of childhood environmental factors on later life outcomes, we derive most of our explanatory variables from the base year 2000 Census short form responses. ${ }^{11}$ We use the Master Address File ID (MAFID) to define a

admitted into subsidized housing after a household member develops a disability. Again, under the assumption that exposure to this disability worsens potential labor market outcomes, this would lead to a downward-biased estimate.

${ }^{11}$ We chose to use all households in the U.S. rather than the 1-in-6 sample filling out the long form for the 
household as the set of responses collected from one address. We retain responses for one or two parents as well as all children between the ages of 13 and $18 .{ }^{12}$ We use time-invariant explanatory variables relating to the child such as date of birth, gender, race, and ethnicity, and the household such as housing tenure (rent or own), number of people, number of children. ${ }^{13}$ We also construct a household race/ethnicity variable to allocate households to subsamples. Specifically, we define a household as Hispanic if any member reports being Hispanic, Black non-Hispanic (Black) if no member reports being Hispanic and at least one member reports being Black, White non-Hispanic (White) if no member reports being Hispanic or Black and at least one member reports being White, and Other non-Hispanic (Other) if no member reports being Hispanic, Black, or White.

Youth in the Census 2000 frame are then matched to administrative records on housing subsidies, place of residence, and subsequent earnings using a unique person identifier. Personlevel record matching is done by way of a Protected Identification Key (PIK), which is assigned to survey and administrative records based on personally identifying information. The 2000 Census has PIKs for over 89 percent of the person-records, while almost 98 percent of HUD records have a PIK, and all LEHD records have a PIK. We only retain households with a parent who has a PIK and at least two children aged 13 to 18 that have a PIK and non-missing basic characteristics. ${ }^{14}$ From the full sample including records with no PIK, we estimate a logistic regression for whether or not a person response has a PIK, with explanatory variables including the number of persons in a household, the number of children, housing tenure as well as person age, gender, race, ethnicity and state fixed effects based on the year 2000 location. ${ }^{15}$ To retain a representative sample of records with a PIK, we reweight them using the inverse of the probability of having a PIK, based on the model.

principal analysis in order to have a larger sample size. While the long form would allow us to include variables such as parent's education, such time-invariant explanatory factors will be subsumed into the household fixed effects in any case.

${ }^{12}$ We define the head of household and the spouse of the head of household as the parents for each MAFID. In some cases these individuals may be grandparents, other relatives, or even unrelated adults.

${ }^{13}$ We exclude households including more than 15 residents or more than 10 teenagers.

${ }^{14}$ For cases where a PIK has been assigned to multiple responses (less than 1 percent) we drop all cases, unless all observable characteristics (date of birth, race, ethnicity, gender, geographic location) are identical, in which case one record is retained.

${ }^{15}$ Characteristics highly associated with not having a PIK include race, ethnicity, age, and sex. 


\subsection{Housing subsidy}

The HUD-PIC file provides detailed information on public housing and Housing Choice Voucher recipients during our study period from 1997 to 2005. As part of their housing occupancy verification process, local housing authorities provide HUD with the identities of residents, which HUD then compiles into an annual relational database. The person-level file used at the Census Bureau includes demographic and housing unit information, but this study only makes use of occupancy as an indicator of housing treatment. ${ }^{16}$ We match PIKs from the decennial file to the HUD-PIC file and identify whether a child resided in public or voucher housing in each year from 1997 to 2005. We consider a child to be a HUD-subsidized resident in a particular year if their PIK appears in the HUD administrative data and if that individual is still under the age of $18 .{ }^{17}$ Thus, the maximum number of years a child could reside in HUD housing is 6 years before turning 18, which could occur for a 13-year-old first residing in subsidized housing in or before 2000. An 18-year-old in 2000 could only reside in HUD-subsidized housing for at most 4 years (beginning in 1997).

We construct an indicator variable for whether a teen resided in either public or voucher housing any time between 1997 and 2005. Our goal is to estimate the effect of this binary treatment variable on labor market outcomes. We also examine the effect of a treatment "dose" variable that could take on values from 0 to 6 for the count of (post-1996) years a child resides in voucher or public housing.

\subsection{Labor market outcomes}

LEHD, a partnership between the Census Bureau and all 50 states and the District of Columbia, produces public use data tabulations (both Quarterly Workforce Indicators and an interactive web-based commuting analysis tool, OnTheMap) that are widely used by state and local governments. At its core are two administrative records files provided by states on a quarterly basis: (1) unemployment insurance (UI) wage records, giving the earnings of each worker at each employer, and (2) employer reports giving establishment-level data, also known as the Quarterly Census of Employment and Wages (QCEW), but often referred to as the 'ES-

\footnotetext{
${ }^{16}$ Table B-1 in Appendix B presents the percentage of records with non-missing data in the PIC administrative file. Other tables there present some characteristics of the PIC sample.

${ }^{17}$ We do not count individuals who are under 18 in 2000 but over 18 when we observe them in the HUD administrative data as being HUD residents.
} 
202' program. The coverage is roughly 96 percent of private non-farm wage and salary employment (Stevens, 2007). ${ }^{18}$

The longitudinal LEHD data are based on quarterly earnings information for more than 130 million U.S. workers and their employers covered under state UI systems beginning in the mid-1990s and continuing to the present, essentially a universe of workers. The longitudinal data thus permit the measurement of complete employment "histories" beginning with a person's entrance into the labor force. This information includes earnings, employment status and industry, along with other work and home location information. Thus, LEHD wage data matched to the Census 2000 data enable us to track a large set of children into adulthood and measure earnings and employment outcomes. For our purposes, the national nature of the files and complete work histories enable one to compute outcome measures for individuals over any given horizon such as the number of quarters worked, cumulative number of jobs, the number of spells of joblessness, the durations of spells of joblessness, and the earnings levels and its growth within and between jobs.

For regression purposes, we use the inverse hyperbolic sine (IHS) of earnings rather than the more traditional log of earnings because estimated coefficients can be interpreted in the same way as with a log transformed dependent variable but, unlike with the log of earnings, IHS is defined for zero earnings. The IHS is defined as $\mathrm{y}_{\mathrm{i}}{ }^{*}=\log \left[\mathrm{y}_{\mathrm{i}}+\left(\mathrm{y}_{\mathrm{i}}^{2}+1\right)^{1 / 2}\right]$ where $y_{i}$ is total earnings for individual $i$. (See Burbidge et al., 1998.)

\subsection{Within-household heterogeneity}

We introduce additional geographic data and earnings normalizations to address timevarying household factors may be associated with siblings residing in subsidized housing, as well as eligibility for a housing subsidy. The LEHD program maintains an annual place of residence file composed of federal administrative data known as the Composite Person Record (CPR). LEHD uses CPR residences, which begin in 1999, for imputation models and for the residence

\footnotetext{
${ }^{18}$ LEHD is in the process of integrating data on self-employed individuals and independent contractors who are not covered in the UI files but are available from the Census Bureau's Business Register which contains the universe of all businesses including all sole proprietorships on an annual basis (whether the sole proprietor has employees or is a non-employer). In addition, the LEHD project has acquired the personnel records from Office of Personnel Management (OPM) so that federal workers are now also tracked in the file system. This study does not yet make use of these new data sources, but may in future versions.
} 
component of the LEHD Origin-Destination Employment Statistics (LODES) data. We identify a residence census block for each child from 1999-2005 where available (approximately 10 percent of children are missing a CPR residence in each year). Where possible, we match the child residence to block group-level tabulations from Census 2000, giving population density, poverty rates, and other neighborhood characteristics.

In addition to using LEHD earnings to construct outcome measures for the teenagers, we use parent's LEHD earnings to construct an annual measure of household income for 1997 to 2005 to use as a control variable. For each teen, we calculate average parents' earnings (the sum of earnings for the head of household and the spouse of the head of household) while they were a teenager (also transformed into the IHS of average income to match the dependent variable). Additionally, we use each household's location in 2000 and household size in 2000 matched to their average parents' LEHD earnings to identify Area Median Income (AMI) figures at the county level. We then create a ratio of parents' earnings to AMI in order to account for the differences in average earnings across regions, which can vary by almost $\$ 75,000$ for metropolitan areas within the U.S. Since local housing authorities often require that a household earn less than 50 percent of AMI to be eligible for assistance, we retain only children in households with an parents' earnings-to-AMI measure below 0.5, so that the analysis sample includes only those widely eligible for the subsidized housing treatment. As with the labor market outcomes, some households may appear to have lower incomes because they do not work in UI-covered employment. In future work, we will assess the significance of such omissions for our sample composition.

We employ both the composite of neighborhood (at the Census block group-level) poverty and the IHS or average annual parents' earnings between the ages of 13-18 as control variables in the regression model. However, one might be concerned that such variables may not be exogenous. Aaronson (1998) examined whether cross-sibling variation in household income is associated with moves across neighborhoods. Likewise, we acknowledge that changes in household income or neighborhood poverty may not only be explanatory factors, but may also be directly associated with moves into and out of subsidized housing. That said, we believe that changes in household income are more likely to be a confounding factor than a causal pathway. On the other hand, because housing authorities assign public housing recipients to a unit upon program entry, changes in block group percent poverty are more likely to reflect a potential 
causal pathway. As such, we prefer to interpret estimates from specifications without longitudinal controls as the true causal effects, those with controls for parents' earnings as a robustness check on the importance of unobserved, time-varying characteristics, and those with controls for block group percent poverty as a test of one potential causal mechanism.

\section{The Sample: Basic Facts}

To be included in the estimation sample, we require that individuals have been between 13 and 18 years of age in the year 2000, have non-missing values for age, gender, ethnicity, and treatment status, have successfully been assigned a unique PIK based on the 2000 Census, and be from the same 2000 household as at least one other teenager. Finally, because not all households are eligible for subsidized housing, we limit our sample to teenagers from households more likely to qualify for housing assistance, with average annual earnings below 50 percent of local AMI (see above). The final sample size is approximately 1.8 million children, composing 821,000 households. For specifications requiring the place of residence of a child to indicate neighborhood poverty rate, the sample falls to approximately 1.7 million children.

Table 2 presents summary statistics for the 1.7-million child sample - the sample with all variables available. The first column presents summary statistics for 13-18 year olds not in subsidized housing, the second column for teens in households with public housing or a housing choice voucher, and the third column represents the difference. Those in assisted housing are much more likely to be Black, to have lower household income, and to be in a neighborhood with a higher poverty rate. ${ }^{19}$ These patterns highlight the importance of addressing sources of heterogeneity across households. In terms of the key economic outcomes we explore in the 200810 period, those in public housing or voucher housing had lower total earnings and worked fewer quarters. Again, these differences are larger for those we have identified in public housing. No causal inferences can be drawn from these differences.

\section{Empirical Results}

\subsection{Samples and specifications}

${ }^{19}$ In other work using the Census 2000 Long Form, which includes more person and household characteristics, we also found that those in assisted housing are more likely to be in the same housing as 5 years ago, have fewer autos per adult, live in units with fewer square feet, have not completed high school, and have a slightly higher probability of having a household member with a disability. 
The key question we address is whether living in voucher-supported or public housing affects a teenager's labor market experiences as an adult. We compare the effects of each of the two HUD housing with nonsubsidized housing. In this version of the paper, we focus on earnings over the 2008 to 2010 period as our measure of labor market performance. ${ }^{20}$

Table 3 presents results for all households while Tables 4, 5, and 6 present results for teenagers from Black non-Hispanic households, White non-Hispanic households and Hispanic households, respectively. Each table presents results for a "dummy treatment," which consists of a binary measure of whether an individual ever participated in each type of subsidized housing as a teenager, and a "dose treatment," which is defined as the number of years an individual participated in each type of subsidized housing while under the age of 18 . As described above, the dependent variable is the inverse hyperbolic sine of total earnings over the 2008-10 period, and unlisted controls are included for age, gender, age by gender, and household race/ethnicity by gender. We interact race/ethnicity with male in order to capture differences in outcomes given gender, across race/ethnicity groups. Table 7 presents the average partial effect of each type of treatment, separately for each sex and household race type. In addition, Table 7 compares the estimated average partial effect across the two subsidized housing types within each possible sex/household race combination.

In tables 3 through 6, the first column presents estimates from an Ordinary Least Squares specification, as described in equation (1). The coefficients capture the correlation between earnings and the two different types of subsidized housing participation after controlling for observed covariates, but we know as described above that these coefficient estimates might be subject to selection bias. By interacting the treatment variables with gender, we also allow the association with housing to differ by gender. We only report coefficient estimates for the two types of subsidized housing participation and their interactions with gender. The second column in each table presents estimates from a household fixed effects (HFE) specification, described in equation (2). As discussed above, by using only within-household variation, these estimates purge the treatment effects of all bias resulting from time-invariant, household-level unobserved

\footnotetext{
${ }^{20}$ In unreported results, we have also used the total number of quarters worked over the 2008 to 2010 period and an indicator for whether the individual ever worked during the 2008 to 2010 period as dependent variables. The results are qualitatively consistent regardless of which measure of labor market performance is used. We will report those results in a later paper.
} 
characteristics. We believe these estimates better capture the causal effect of subsidized housing participation as a teenager on adult labor market earnings.

The third column in each table presents results from a HFE specification that also includes a control for the average parents' earnings that each individual experienced between 13 and 18 and its interaction with a male dummy. Finally, the fourth column presents results from a HFE specification that controls for parents earnings and average block group percent poverty that each individual experienced between 13 and 18 years of age. We interpret the estimates in Column 3 as a test for whether our household fixed effects are effectively ridding the treatment effects of bias from unobserved, time-varying heterogeneity. Specifically, if our treatment effects do not change after the inclusion of parents' earnings, then either the within-household differences in subsidized housing participation or the within-household differences in adult earnings (or both) are unrelated to within-household differences in parents' earnings. We interpret the change in the estimates between Columns 3 and 4 as an indicator of whether neighborhood quality, as proxied for by block-group percent poverty, is a potential mechanism for the estimated treatment effects.

\subsection{Results for all households}

We now turn to the coefficients of interest beginning with the estimates that pool across household race/ethnicity in Table 3. In column one, for both the dummy and dose treatments, the OLS results show that there are significant and similar negative effects on subsequent total earnings of living in voucher-supported housing and public housing. For the dummy treatment, at the means of the other control variables, residence in voucher housing as a teenager is associated with young adult earnings that are 44 percent lower for females and 53 percent lower for males. The corresponding estimates for public housing are 45 and 42 percent lower, respectively. The dose treatment effects show an 11 percent decrease in earnings per year of voucher housing participation for females, and 13 percent decrease for males. For public housing, the estimates suggest an extra year of teenage public housing participation is associated with a 12 percent decrease in earnings for females and a 10 percent decrease in earnings for males. Significant negative relationships between the two types of subsidized housing participation and adult earnings also occur in each of the race/ethnicity groups (Tables 4-6), although magnitudes vary. 
However, The HFE results, based on controlling for all household level time-invariant heterogeneity, paint an entirely different picture; the HFE results for females and males are summarized in Column 2. The negative effects found using OLS are in most cases attenuated or reversed. Housing voucher participation is no longer negatively related to adult earnings for females. The effect of voucher participation remains negative and statistically significant for males with the dummy treatment and just below zero but insignificant with the dose treatment. But in any event, the effect on males is significantly less than that for females. The point estimate suggests that ever having participated in voucher-supported housing as a teenager reduces adult earnings by roughly 10 percent for males. The dose results indicate that each additional year of voucher participation reduces early adult earnings for males by 1 percent. For public housing, the relationship between participation and future earnings is now insignificant, for males and females for both the dummy and dose results. Comparing the effects of voucher housing with those of public housing, we find no significant differences in the (relatively small) male or female results.

The results in columns 3 and 4, which add the controls for average parents' earnings and average block group percent poverty, are essentially unchanged. In what follows, we find that columns 2 and 3 are similar even when we consider results for different race/ethnicity samples and regardless of whether we define treatment as a dummy or a dose measure. We believe this indicates that the household fixed effects specification is effectively ridding the treatment effects of bias from unobserved, time-varying heterogeneity.

\subsection{Race/ethnicity samples}

To help understand the results in Table 3, we turn to results by household race/ethnicity. In particular, the absence of positive and significant effects for females is at variance with some findings reported in the literature. Tables 4 through 6 thus explore whether there is treatment effect heterogeneity by household race/ethnicity by estimating coefficients separately for White non-Hispanic households, Black non-Hispanic households and Hispanic households, respectively. Again, we focus on the effects of the HFE specification summarized in Table 7. Comparing results across these three subgroups, we find important differences. For example, comparing the HFE results shows substantial positive effects on young adult earnings for Blacks, but not for Hispanics or for non-Hispanic Whites. A similar result also exists for public housing. 
Clearly, there are different treatment effects across groups, affirming the importance of considering these groups separately. With this in mind, we turn to the results by race/ethnicity group.

The HFE estimates in Table 4 indicate that voucher-supported housing participation as a teenager decreases White female earnings. In the dummy case, the effect is statistically significant for females, suggesting a decrease in adult earnings of nearly 11 percent among those who ever participated in in voucher-supported housing. The effect is not significant when considering the dose treatment. The point estimates for males in voucher housing, are not significant (although again there is statistically significantly difference between males and females -- the effect for males is more positive). For public housing, the pattern appears similar: female earnings are decreased while male earnings are increased by public housing participation, though these results are statistically significant only when using the dummy treatment variable. In all specifications, the effect of public housing on males is significantly more positive than it is for females. For White households, the inclusion of the neighborhood changes across siblings has little effect. Similarly, for both dummy and dose, including the control for parents' earnings does not change the estimates.

Table 5 presents the results for teenagers from non-Hispanic Black households. Despite a smaller sample size than for the other two race/ethnicity groups, the estimated coefficients are much more precise reflecting both an increased likelihood of assisted housing participation and an increased likelihood of within-household differences in assisted housing participation. The effects of living in public or voucher housing are positive, substantial, and significant for Black females. The effect on Black males is now insignificant. These results suggest that both voucher participation and living in public housing both improve labor market outcomes. The point estimates suggest that females earn 21 percent more if they ever resided in voucher housing and 18 percent more if they ever resided in public housing. The corresponding estimates from the dose treatment indicate that each additional year of voucher-supported housing participation increases earnings by 7 percent for females, while each additional year of public housing also increases female earnings by 7 percent. While the male interaction terms are always signed negative (and often significant), the overall estimated treatment effects for males are only significantly different from zero with the dose treatment variable for public housing. This suggests that each year of public housing participation as a teenager increases adult earnings by 5 
percent for males. As was the case with the overall and the White non-Hispanic samples, including the control for parents' earnings has no effect; the point estimates in Columns 2 and 3 are almost identical. Column 4 of Table 5 includes the measure of neighborhood poverty, which has the expected negative effect on earnings. Including poverty diminishes the estimated effect of public housing, suggesting that changes in neighborhood quality may explain part of the causal pathway through which public housing affects adult earnings.

Table 6 presents the same set of results for teenagers from Hispanic families. These effects become much smaller and insignificantly different from zero in all but one case after including household fixed effects. The lone significant result is that for both females and males who ever participated in voucher housing, there is a reduction in adult earnings of about 16 percent. Once again, the inclusion of parents' earnings as a control has no impact on the estimated coefficients.

Table 7, in addition to displaying the average partial effects of each type of subsidized housing separately by individual sex also tests whether the effects of each type of subsidized housing are equal. For example, we test whether the effect of voucher housing for females is the same as the effect of public housing for females. We conduct this test for each possible household race/sex combination, and for both the dummy and dose treatments. For the combined sample, we find that vouchers lead to lower male outcomes than public housing for both the dummy and dose treatments, and we reject the null that the two treatment effects are equal. For most of the race/ethnicity samples, the effects are not statistically distinguishable.

\section{Concluding Comments}

In spite of the policy importance of understanding the effects of subsidized rental housing, the literature is deficient with regard to long-term effects for multiple types of assistance programs. In this paper, we report preliminary results from a project that fills important gaps in this literature. In particular, we take an intergenerational approach by studying longer-term effects of children's housing on their adult employment and earnings, using largescale national data and empirical strategies aimed at addressing the inherent difficulties in estimating causal effects of housing.

Our use of national data on housing assistance, households, and earnings from administrative records, censuses, and surveys at the U.S. Census Bureau makes these 
contributions possible. These data permit us to identify households with children between the ages of 13-18 in the year 2000, follow those children across a variety of settings of assisted and unassisted rental housing, and then to investigate those teenagers' employment and earnings up to 10 years later.

We recognize in the analysis that unobserved heterogeneity and the associated selection bias is an obstacle to estimating causal effects of housing. To overcome this issue, we exploit the very large sample size and longitudinal nature of the data. Our preferred specification is a household fixed effects model that identifies the impact of public housing by exploiting the variation in the timing of when or whether siblings within an assisted household are in such assisted housing. We also consider a specification including household factors that may vary across children, including parent's income and average neighborhood poverty, but these do not affect our overall estimates of the effects of subsidized housing on young adult earnings. One main finding is that the substantial negative average effect on a particular outcome often associated in the literature with a child living in public housing or assisted rental housing may be largely attributable to selection of households into assisted housing.

We disaggregate our sample by race/ethnicity of a household, to reflect the different contexts in which households select into assisted housing. We find divergent effects, with Blacks benefiting more than Hispanics or non-Hispanic Whites.

The effects of living in public or voucher housing on later earnings are positive, substantial, and significant for non-Hispanic Black female teenagers, but living in public or voucher housing has no effect on the later earnings of non-Hispanic Black male teenagers. The point estimates suggest that females earn 21 percent more if they ever resided in voucher housing and 18 percent more if they ever resided in public housing. The corresponding estimates from the dose treatment indicate that each additional year of voucher-supported housing participation increases earnings by 7 percent for females, while each additional year of public housing also increases female earnings by 7 percent. The overall estimated treatment effects for males suggests that each year of public housing participation as a teenager increases adult earnings by 5 percent for males. Comparing subsidy programs, we see that Black females benefit from both voucher housing and public housing. Black males, on the other hand, benefit more from public housing. 
The findings for Black teenagers are in strong contrast to the findings for non-Hispanic White and Hispanic teenagers. Non-Hispanic White female earnings are decreased by vouchersupported housing participation as a teenager, with an estimated decrease in adult earnings of nearly 11 percent among those who ever participated in in voucher-supported housing. The effect is not significant when considering the dose treatment. The point estimates for males in voucher housing are not significant (although again, there is statistically significantly difference between males and females -- the effect for males is more positive). For public housing, the pattern appears similar to the findings for voucher housing -- public housing participation decreases White female earnings while increasing White male earnings. These results are statistically significant only when using the dummy treatment variable. In all specifications, the effect of public housing on males is significantly more positive than it is for females.

Finally, we find few significant results for Hispanic teenagers. The lone significant results is that for both females and males who ever participated in voucher housing, there is a reduction in adult earnings of about 16 percent.

Though these results seem robust, one should be aware of some limitations. They apply to just two of the many subsidized housing programs, albeit the largest - public housing and housing vouchers. By using the household fixed effects specification, we address the potential selection bias associated with unobservable characteristics, but we introduce the issue that the included households might not be representative of all subsidized households (that is, households with younger children, and those with just one teenager). 


\section{References}

Aaronson, Daniel. 1998. "Using Sibling Data to Estimate the Impact of Neighborhoods on Children's Educational Outcomes.” The Journal of Human Resources 33(4).

Abowd, John, John Haltiwanger and Julia Lane. 2004. "Integrated Longitudinal EmployeeEmployer Data for the United States.” American Economic Review 94(2).

Abowd, John, John Haltiwanger, Ron Jarmin, Julia Lane, Paul Lengermann, Kristin McCue, Kevin McKinney, and Kristin Sandusky. 2005. "The Relationship Between Human Capital, Productivity and Market Value: Building Up From Microeconomic Evidence”. In Carol Corrado, John Haltiwanger, and Daniel Sichel (eds.) Measuring Capital in the New Economy. University of Chicago Press.

Andersson, Fredrik, Harry Holzer and Julia Lane. 2005 Moving Up or Moving On: Who Advances in the Low-Wage Labor Market? Russell Sage Foundation.

Andersson, Fredrik. Matthew Freedman, John Haltiwanger, Julia Lane and Kathryn Shaw. 2009. "Reaching for the Stars: Who Pays for Talent in Innovative Industries?” Economic Journal 119 (June), pp. 308-332.

Andersson, Fredrik, John Haltiwanger, Mark Kutzbach, Henry Pollakowki, and Daniel Weinberg. 2011. "Job Displacement and the Duration of Joblessness: The Role of Spatial Mismatch.” Paper presented at the 2011 January AREUEA Meetings, Denver.

Bania, Neil, Claudia Coulton, and Laura Leete. 2003. "Public Housing Assistance, Public Transportation, and the Welfare-to-Work Transition." Cityscape: A Journal of Policy Development and Research 6(2), pp. 7-44.

Brown, Clair, John Haltiwanger, and Julia Lane. 2006. Economic Turbulence: Is A Volatile Economy Good For America? Chicago: University of Chicago Press.

Burbidge, John B., Lonnie Magee, and A. Leslie Robb, 1988. "Alternative Transformations to Handle Extreme Values of the Dependent Variable" Journal of the American Statistical Association Vol. 83, No. 401, pp. 123-127.

Carlson, Deven, Robert Haveman, Thomas Kaplan, and Barbara Wolfe. 2012a. "Long Term Earnings and Employment Effects of Housing Voucher Receipt.” Journal of Urban Economics 71(1): 128-150.

Carlson, Deven, Robert Haveman, Thomas Kaplan, and Barbara Wolfe. 2012b. “Long-term Effect of Public Low-Income Housing Vouchers on Neighborhood Quality and Household Composition.” Journal of Housing Economics 21: 101-120.

Currie, Janet, Mark Stabile, Phongsack Manivong, and Leslie L. Roos. 2010. “Child Health and Young Adult Outcomes.” Journal of Human Resources 45: 517-548.

Currie, Janet, and Reed Walker. 2011. "Traffic Congestion and Infant Health: Evidence from EZPass.” American Economic Journals-Applied Economics 3: 65-90. 
Currie, Janet, and Aaron Yelowitz. 2000. “Are Public Housing Projects Good For Kids?” Journal of Public Economics 75: 99-124.

Davis, Steven J., John Haltiwanger, and Scott Schuh, 1996, Job Creation and Destruction, MIT Press.

Falk, Gene. 2012. “Low-Income Assistance Programs: Trends in Federal Spending.” Congressional Research Service Report R41823, June.

Fisher, Lynn, Henry O. Pollakowski, and Jeffrey Zabel. 2009. Amenity-Based Housing Affordability Indexes. Real Estate Economics 37(4).

Friedman, Joseph and Daniel H. Weinberg. 1982. The Economics of Housing Vouchers. New York: Academic Press.

Friedman, Joseph and Daniel H. Weinberg (eds.). 1983. The Great Housing Experiment. Los Angeles: SAGE Publications Urban Affairs Annual Reviews.

Galster, George and Anna Maria Santiago. 2008. "Magnitudes and Mechanisms of Neighborhood Impacts on Children: Analyzing a Natural Experiment in Denver.” 2008 recipients of MacArthur Foundation grant program How Housing Matters.

Griliches, Z. 1979. “Sibling Models and Data in Economics: Beginnings of a Survey.” Journal of Political Economy 87: S37-S64.

Imbens, Guido M. and Thomas Lemieux. 2007. Regression Discontinuity Designs: A Guide to Practice. Cambridge, MA: National Bureau of Economic Research. Working Paper 13039.

Imbens, Guido M. and Jeffrey M. Wooldridge. 2007. Recent Developments in the Econometrics of Program Evaluation. Cambridge, MA: National Bureau of Economic Research. Working Paper 14251.

Jacob, Brian A. 2004. "Public Housing, Housing Vouchers, and Student Achievement: Evidence from Public Housing Demolitions in Chicago.” American Economic Review 94(1): 233258.

Jacob, Brian A. and Jens Ludwig. 2012. "The Effects of Housing Assistance on Labor Supply: Evidence from a Voucher Lottery.” American Economic Review 102:1: 272-304.

Kain, John F. 1964. The Effects of the Ghetto on the Distribution of Nonwhite Employment in Urban Areas. Washington, DC: National Academy Press.

Kain, John F. 1968. "Housing Segregation, Negro Employment, and Metropolitan Decentralization.” Quarterly Journal of Economics 82 (1) (February), pp. 32-59.

Lubell, Jeffrey M., 2003. Mark Shroder and Barry Steffen. "Work Participation and Length of Stay in HUD-Assisted Housing." Cityscape: A Journal of Policy Development and Research 6(2) 207-223.

Mills, Gregory, Daniel Gubits, Larry Orr, David Long, Judie Feins, Bulbul Kaul, Michelle Wood, Amy Jones \& Associates, Cloudburst Consulting, and the QED Group. 2006. The Effects of Housing Vouchers on Welfare Families. Washington, DC: U.S. Department of Housing and Urban Development, Office of Policy Development and Research. 
McDade, Thomas. 2008.” The Effects of Housing Vouchers on Long-Term Health Outcomes.” 2008 recipient of MacArthur Foundation grant program How Housing Matters.

Newman, Sandra and Joseph Harkness. 2000. "Assisted Housing and the Educational Attainment of Children.” Journal of Housing Economics 9: 40-63.

Newman, O. Defensible Space. New York: Macmillan. 1972.

Olsen, Edgar O. 2003. "Housing Programs for Low-Income Households.” In Robert A. Moffitt (ed.) Means-Tested Transfer Programs in the United States. National Bureau of Economic Research.

Olsen, Edgar O. and Catherine A. Tyler, Jonathan W. King, and Paul E. Carrillo. 2005. "The Effects of Different Types of Housing Assistance on Earnings and Employment.” Cityscape: A Journal of Policy Development and Research 8(2) 163-187.

Oreopoulos, Philip. 2003. "The Long-Run Consequences of Living in a Poor Neighborhood.” Quarterly Journal of Economics 118(4): 1533-1575.

Orr, Larry, Judith D. Feins, Robin Jacob, and Erik Beecroft. 2003. Moving to Opportunity Interim Impacts Evaluation. Washington, DC: U.S. Department of Housing and Urban Development, Office of Policy Development and Research.

Popkin, Susan J., Diane K. Levy, Laura E. Harris, Jennifer Comey, Mary K. Cunningham, and Larry F. Buron. 2004. “The HOPE VI Program: What about the Residents?” Housing Policy Debate 15: 385-414.

Eriksen, Michael D. and Stuart S. Rosenthal. 2010. "Crowd Out Effects of Place-Based Subsidized Rental Housing: New Evidence from the LIHTC Program.” Working Paper.

Rosenbaum, James E. 1995. "Changing the Geography of Opportunity by Expanding Residential Choice: Lessons from the Gautreaux Program.” Housing Policy Debate 6:1, pp. 231-269.

Royer, Heather. 2009. "Separated at Girth: Estimating the Long-Run and Intergenerational Effects of Birthweight Using Twins.” American Economic Journal: Applied Economics 1: 49-85.

Sanbonmatsu, Lisa, Jens Ludwig, Lawrence F. Katz, Lisa A. Gennetian, Greg J. Duncan, Ronald C. Kessler, Emma Adam, Thomas W. McDade, Stacy Tessler Lindau. 2011. "Moving to Opportunity for Fair Housing Demonstration Program - Final Impacts Evaluation." U.S. Department of Housing and Urban Development, Office of Policy Development \& Research.

Shroder, Mark. 2002. "Does Housing Assistance Perversely Affect Self-Sufficiency? A Review Essay.” Journal of Housing Economics 11: 381-417.

Stevens, David. 2007. "Employment That Is Not Covered by State Unemployment Insurance Laws.” U.S. Census Bureau LEHD Technical Paper No. TP-2007-04.

Susin, Scott. 2005. "Longitudinal Outcomes of Subsidized Housing Recipients in Matched Survey and Administrative Data." Cityscape: A Journal of Policy Development and Research 8(2): 189-218. 
Tatian, Peter A. and Christopher Snow. 2005. "The Effects of Housing Assistance on Income, Earnings, and Employment.” Cityscape: A Journal of Policy Development and Research $8(2) ; 135-161$.

Tornqvist, Leo, Pentti Vartia and Yrjo Vartia, 1985, "How Should Relative Change Be Measured?” American Statistician February, 39:1, pp. 43-46.

U.S. Department of Housing and Urban Development. 2011. Moving to Opportunity for Fair Housing Demonstration Program: Final Impacts Evaluation. U.S. Department of Housing and Urban Development, Washington D.C.

Weinberg, Daniel. 1982. "Housing Benefits from the Section 8 Housing Program.” Evaluation Review 6(1): 5-24.

Woolridge, Jeffrey. 2002. Econometric Analysis of Cross Section and Panel Data. Cambridge: MIT Press. 
Table 1: Characteristics of Households Receiving Federal Rental Subsidies in the Form of Public Housing or Vouchers, 2000

\begin{tabular}{lrr}
\hline \hline & $\begin{array}{c}\text { Public } \\
\text { Housing }\end{array}$ & $\begin{array}{c}\text { Voucher- } \\
\text { Supported } \\
\text { Housing }\end{array}$ \\
\hline Number of People per Unit & 2.3 & 2.7 \\
Rent per Month & $\$ 202$ & $\$ 226$ \\
Household Income per Year & $\$ 10,000$ & $\$ 10,600$ \\
Average Months on Waiting List & 15 & 26 \\
Average Months Since Moved In & 107 & 52 \\
Percent of Households where Majority of & $11 \%$ & $12 \%$ \\
Income is Derived from Welfare & & \\
Percent of Metropolitan Area Median Income & 25 & 23 \\
Percent of Households with Children & 45 & 61 \\
Percent Minority & 69 & 61 \\
Percent Moved in Past Year & 10 & 15 \\
Percent with 0 or 1 Bedrooms & 48 & 25 \\
Percent with 2 Bedrooms & 25 & 39 \\
Percent with 3 or more Bedrooms & 27 & 35 \\
\hline & & \\
Total Units & $\mathbf{1 , 2 8 2 , 0 9 9}$ & $\mathbf{1 , 8 1 7 , 3 6 0}$ \\
\hline \hline
\end{tabular}

SOURCE: HUDUSER, HUD Public Use Data. 
Table 2. Summary Statistics for Teenagers in Households with Parent Earnings Below 50 Percent of Area Median Income in 2000

\begin{tabular}{|c|c|c|c|}
\hline Variable & $\begin{array}{r}\text { No } \\
\text { Subsidized } \\
\text { Housing } \\
\text { Participation } \\
\end{array}$ & $\begin{array}{r}\text { Some } \\
\text { Subsidized } \\
\text { Housing } \\
\text { Participation } \\
\end{array}$ & Difference \\
\hline Household Size in 2000 & 5.335 & 5.428 & -0.093 \\
\hline Teenager Age in 2000 & 15.301 & 15.193 & 0.108 \\
\hline Male & 0.515 & 0.482 & 0.033 \\
\hline Black Non-Hispanic & 0.162 & 0.488 & -0.327 \\
\hline Hispanic & 0.157 & 0.198 & -0.042 \\
\hline Other Race Non-Hispanic & 0.062 & 0.069 & -0.007 \\
\hline White Non-Hispanic & 0.620 & 0.244 & 0.375 \\
\hline Rental Housing in 2000 & 0.285 & 0.828 & -0.543 \\
\hline Rent-Free Housing in 2000 & 0.022 & 0.026 & -0.004 \\
\hline $\begin{array}{l}\text { Owner-Occupied Housing in } \\
2000\end{array}$ & 0.693 & 0.147 & 0.547 \\
\hline $\begin{array}{l}\text { Average Block Group Percent } \\
\text { Poverty Ages 13-18 }\end{array}$ & 0.133 & 0.239 & -0.106 \\
\hline $\begin{array}{l}\text { Average Parents Earnings Ages } \\
13-18\end{array}$ & 10,000 & 8,000 & 2000 \\
\hline $\begin{array}{l}\text { Average Inverse Hyperbolic Sine } \\
\text { of Parent Earnings Ages 13-18 }\end{array}$ & 7.282 & 7.426 & -0.145 \\
\hline $\begin{array}{l}\text { Total Labor Market Earnings } \\
\text { Between } 2008 \text { and } 2010\end{array}$ & 35,000 & 25,000 & 10,000 \\
\hline $\begin{array}{l}\text { Inverse Hyperbolic Sine of Teen } \\
\text { Earnings Between } 2008 \text { and } 2010\end{array}$ & 8.704 & 8.23 & 0.474 \\
\hline $\begin{array}{l}\text { Total Number of Quarters } \\
\text { Worked Between } 2008 \text { and } 2010\end{array}$ & 7.156 & 6.493 & 0.663 \\
\hline $\begin{array}{l}\text { Any Labor Market Earnings } \\
\text { Between } 2008 \text { and } 2010\end{array}$ & 0.81 & 0.801 & 0.009 \\
\hline $\begin{array}{l}\text { Observations (to nearest } \\
\text { thousand) }\end{array}$ & $1,487,000$ & 190,000 & \\
\hline
\end{tabular}

SOURCE: Authors’ calculations from matched Census 2000-LEHD-PIC file.

NOTES: Table 2 presents summary statistics by subsidized housing participation while under the age of eighteen. In each row, Column 1 presents the mean for those teenagers who never participated in subsidized housing while under eighteen, Column 2 presents the mean for those teenagers who ever participated in subsidized housing while under eighteen, and Column 3 presents the difference between Columns 1 and 2. All differences in Column 3 are significant at the 0.001 level. 
Table 3. The Effect of Teenage Residence in HUD-Subsidized Housing on Total 2008-2010 Earnings

\begin{tabular}{|c|c|c|c|c|}
\hline Dummy Treatment & OLS & HFE & $\begin{array}{c}\text { HFE With } \\
\text { Control for } \\
\text { Parents' } \\
\text { Earnings While } \\
\text { a Teenager } \\
\end{array}$ & $\begin{array}{l}\text { HFE with } \\
\text { Controls for } \\
\text { Parents' } \\
\text { Earnings and } \\
\text { Neighborhood }\end{array}$ \\
\hline Voucher & $\begin{array}{c}-0.438 * * * \\
(0.017)\end{array}$ & $\begin{array}{c}0.010 \\
(0.034)\end{array}$ & $\begin{array}{c}0.010 \\
(0.034)\end{array}$ & $\begin{array}{c}-0.004 \\
(0.036)\end{array}$ \\
\hline Voucher*Male & $\begin{array}{c}-0.094 * * * \\
(0.026)\end{array}$ & $\begin{array}{c}-0.090 * * * \\
(0.031)\end{array}$ & $\begin{array}{c}-0.089 * * * \\
(0.031)\end{array}$ & $\begin{array}{c}-0.092^{* * *} \\
(0.033)\end{array}$ \\
\hline Public Housing & $\begin{array}{c}-0.450 * * * \\
(0.023)\end{array}$ & $\begin{array}{c}0.039 \\
(0.044)\end{array}$ & $\begin{array}{c}0.039 \\
(0.044)\end{array}$ & $\begin{array}{c}0.026 \\
(0.046)\end{array}$ \\
\hline Public Housing*Male & $\begin{array}{c}0.028 \\
(0.035)\end{array}$ & $\begin{array}{c}0.010 \\
(0.043)\end{array}$ & $\begin{array}{c}0.011 \\
(0.043)\end{array}$ & $\begin{array}{l}-0.003 \\
(0.046)\end{array}$ \\
\hline Constant & $\begin{array}{c}8.566^{* * *} \\
(0.011)\end{array}$ & $\begin{array}{c}8.749 * * * \\
(0.013)\end{array}$ & $\begin{array}{c}8.808 * * * \\
(0.058)\end{array}$ & $\begin{array}{c}8.885^{* * *} \\
(0.065)\end{array}$ \\
\hline Observations & $1,801,000$ & $1,801,000$ & $1,801,000$ & $1,675,000$ \\
\hline R-squared & 0.011 & 0.008 & 0.008 & 0.009 \\
\hline Number of Households & & 821,000 & 821,000 & 804,000 \\
\hline Dose Treatment & OLS & HFE & $\begin{array}{c}\text { HFE With } \\
\text { Control for } \\
\text { Parents' } \\
\text { Earnings While } \\
\text { a Teenager }\end{array}$ & $\begin{array}{c}\text { HFE with } \\
\text { Controls for } \\
\text { Parents' } \\
\text { Earnings and } \\
\text { Neighborhood }\end{array}$ \\
\hline Voucher & $\begin{array}{c}-0.106^{* * *} \\
(0.005)\end{array}$ & $\begin{array}{c}0.016 \\
(0.010)\end{array}$ & $\begin{array}{c}0.016 \\
(0.010)\end{array}$ & $\begin{array}{c}0.013 \\
(0.011)\end{array}$ \\
\hline Voucher*Male & $\begin{array}{c}-0.024^{* * *} \\
(0.007)\end{array}$ & $\begin{array}{c}-0.022^{* * *} \\
(0.008)\end{array}$ & $\begin{array}{c}-0.022 * * * \\
(0.008)\end{array}$ & $\begin{array}{c}-0.021 * * \\
(0.009)\end{array}$ \\
\hline Public Housing & $\begin{array}{c}-0.121^{* * *} \\
(0.007)\end{array}$ & $\begin{array}{c}0.024 \\
(0.015)\end{array}$ & $\begin{array}{c}0.024 \\
(0.015)\end{array}$ & $\begin{array}{c}0.017 \\
(0.016)\end{array}$ \\
\hline Public Housing*Male & $\begin{array}{c}0.017 \\
(0.010)\end{array}$ & $\begin{array}{c}0.010 \\
(0.012)\end{array}$ & $\begin{array}{c}0.011 \\
(0.012)\end{array}$ & $\begin{array}{c}0.008 \\
(0.013)\end{array}$ \\
\hline Constant & $\begin{array}{c}8.562 * * * \\
(0.011)\end{array}$ & $\begin{array}{c}8.743^{* * *} \\
(0.013)\end{array}$ & $\begin{array}{c}8.802 * * * \\
(0.058)\end{array}$ & $\begin{array}{c}8.878 * * * \\
(0.065)\end{array}$ \\
\hline Observations & $1,801,000$ & $1,801,000$ & $1,801,000$ & $1,675,000$ \\
\hline R-squared & 0.011 & 0.008 & 0.008 & 0.009 \\
\hline Number of Households & & 821,000 & 821,000 & 804,000 \\
\hline
\end{tabular}

Source: Authors' tabulations from matched Census 2000-LEHD-PIC file. 
Notes: OLS = Ordinary Least Squares. HFE = Household Fixed Effects. Observations rounded to the nearest thousand. Sample limited to households with parents earning below 50 percent or less of HUD's county-level average Area Median Income. The dependent variable in each column is the inverse hyperbolic sine of total earnings between 2008 and 2010. All columns include controls for age, sex, age by sex, and household race by sex. Column 3 also includes a control for the inverse hyperbolic sine of average parents' annual earnings while a teenager. Column 4 includes everything in Column 3 and a control for the average block group percent poverty experienced while a teenager. Standard Errors in Parentheses. *** $\mathrm{p}<0.01,{ }^{* *} \mathrm{p}<0.05,{ }^{*} \mathrm{p}<0.1$

Table 4. The Effect of Teenage Residence in HUD-Subsidized Housing on Total 2008-2010 Earnings, Non-Hispanic White Households

\begin{tabular}{|c|c|c|c|c|}
\hline Dummy Treatment & OLS & HFE & $\begin{array}{l}\text { HFE With } \\
\text { Control for } \\
\text { Parents' } \\
\text { Earnings While } \\
\text { a Teenager }\end{array}$ & $\begin{array}{l}\text { HFE with } \\
\text { Controls for } \\
\text { Parents' } \\
\text { Earnings and } \\
\text { Neighborhood }\end{array}$ \\
\hline Voucher & $\begin{array}{c}-0.390 * * * \\
(0.033)\end{array}$ & $\begin{array}{c}-0.108^{*} \\
(0.060)\end{array}$ & $\begin{array}{c}-0.105^{*} \\
(0.060)\end{array}$ & $\begin{array}{c}-0.109 * \\
(0.064)\end{array}$ \\
\hline Voucher*Male & $\begin{array}{c}0.093^{*} \\
(0.048)\end{array}$ & $\begin{array}{c}0.171^{* * *} \\
(0.059)\end{array}$ & $\begin{array}{c}0.166^{* * *} \\
(0.059)\end{array}$ & $\begin{array}{c}0.079 \\
(0.063)\end{array}$ \\
\hline Public Housing & $\begin{array}{c}-0.279 * * * \\
(0.052)\end{array}$ & $\begin{array}{c}-0.237 * * * \\
(0.085)\end{array}$ & $\begin{array}{c}-0.232^{* * *} \\
(0.085)\end{array}$ & $\begin{array}{c}-0.196 * * \\
(0.090)\end{array}$ \\
\hline Public Housing*Male & $\begin{array}{c}0.411^{* * *} \\
(0.077)\end{array}$ & $\begin{array}{c}0.404^{* * *} \\
(0.095)\end{array}$ & $\begin{array}{c}0.395^{* * *} \\
(0.095)\end{array}$ & $\begin{array}{c}0.277 * * * \\
(0.100)\end{array}$ \\
\hline Constant & $\begin{array}{c}8.654 * * * \\
(0.014)\end{array}$ & $\begin{array}{c}8.639 * * * \\
(0.015)\end{array}$ & $\begin{array}{c}8.757 * * * \\
(0.067)\end{array}$ & $\begin{array}{c}8.837 * * * \\
(0.076)\end{array}$ \\
\hline Observations & $1,027,000$ & $1,027,000$ & $1,027,000$ & 953,000 \\
\hline R-squared & 0.001 & 0.002 & 0.002 & 0.002 \\
\hline Number of Households & & 477,000 & 477,000 & 467,000 \\
\hline Dose Treatment & OLS & HFE & $\begin{array}{c}\text { HFE With } \\
\text { Control for } \\
\text { Parents' } \\
\text { Earnings While } \\
\text { a Teenager } \\
\end{array}$ & $\begin{array}{l}\text { HFE with } \\
\text { Controls for } \\
\text { Parents' } \\
\text { Earnings and } \\
\text { Neighborhood }\end{array}$ \\
\hline Voucher & $\begin{array}{c}-0.114^{* * *} \\
(0.010)\end{array}$ & $\begin{array}{l}-0.011 \\
(0.020)\end{array}$ & $\begin{array}{l}-0.010 \\
(0.020)\end{array}$ & $\begin{array}{l}-0.010 \\
(0.021)\end{array}$ \\
\hline Voucher*Male & $\begin{array}{c}0.016 \\
(0.014)\end{array}$ & $\begin{array}{c}0.032 * \\
(0.017)\end{array}$ & $\begin{array}{l}0.031^{*} \\
(0.017)\end{array}$ & $\begin{array}{c}0.009 \\
(0.018)\end{array}$ \\
\hline Public Housing & $\begin{array}{c}-0.079 * * * \\
(0.018)\end{array}$ & $\begin{array}{c}-0.048 \\
(0.034)\end{array}$ & $\begin{array}{l}-0.047 \\
(0.034)\end{array}$ & $\begin{array}{l}-0.034 \\
(0.036)\end{array}$ \\
\hline Public Housing*Male & $\begin{array}{c}0.104^{* * *} \\
(0.025)\end{array}$ & $\begin{array}{c}0.097 * * * \\
(0.030)\end{array}$ & $\begin{array}{c}0.095 * * * \\
(0.030)\end{array}$ & $\begin{array}{c}0.052 * \\
(0.031)\end{array}$ \\
\hline Constant & $\begin{array}{c}8.653^{* * *} \\
(0.014) \\
\end{array}$ & $\begin{array}{c}8.634^{* * *} \\
(0.015) \\
\end{array}$ & $\begin{array}{c}8.754 * * * \\
(0.067) \\
\end{array}$ & $\begin{array}{c}8.835 * * * \\
(0.076)\end{array}$ \\
\hline Observations & $1,027,000$ & $1,027,000$ & $1,027,000$ & 953,000 \\
\hline R-squared & 0.001 & 0.002 & 0.002 & 0.002 \\
\hline
\end{tabular}


Number of Households

477,000

477,000

467,000

Source and Notes: See Table 3.

Table 5. The Effect of Teenage Residence in HUD-Subsidized Housing on

Total 2008-2010 Earnings, Non-Hispanic Black Households

\begin{tabular}{|c|c|c|c|c|}
\hline Dummy Treatment & OLS & HFE & $\begin{array}{c}\text { HFE With } \\
\text { Control for } \\
\text { Parents' Earnings } \\
\text { While a Teenager }\end{array}$ & $\begin{array}{c}\text { HFE with } \\
\text { Controls for } \\
\text { Parents’ Earnings } \\
\text { and } \\
\text { Neighborhood }\end{array}$ \\
\hline Voucher & $\begin{array}{c}-0.235^{* * *} \\
(0.023)\end{array}$ & $\begin{array}{c}0.207 * * * \\
(0.051)\end{array}$ & $\begin{array}{l}.205 * * * \\
(-0.051)\end{array}$ & $\begin{array}{c}0.190 * * * \\
(0.053)\end{array}$ \\
\hline Voucher*Male & $\begin{array}{c}-0.223^{* * *} \\
(0.038)\end{array}$ & $\begin{array}{c}-0.282 * * * \\
(0.048)\end{array}$ & $\begin{array}{c}-0.278^{* * *} \\
(0.048)\end{array}$ & $\begin{array}{c}-0.264^{* * *} \\
(0.050)\end{array}$ \\
\hline Public Housing & $\begin{array}{c}-0.311^{* * *} \\
(0.028)\end{array}$ & $\begin{array}{c}0.179 * * * \\
(0.060)\end{array}$ & $\begin{array}{l}.178^{* * *} \\
(0.060)\end{array}$ & $\begin{array}{c}0.087 \\
(0.063)\end{array}$ \\
\hline Public Housing*Male & $\begin{array}{c}-0.112 * * \\
(0.047)\end{array}$ & $\begin{array}{c}-0.148 * * \\
(0.059)\end{array}$ & $\begin{array}{l}-.149 * * \\
(0.059)\end{array}$ & $\begin{array}{l}-0.006 \\
(0.063)\end{array}$ \\
\hline Constant & $\begin{array}{c}8.884 * * * \\
(0.022) \\
\end{array}$ & $\begin{array}{c}8.692 * * * \\
(0.028) \\
\end{array}$ & $\begin{array}{c}8.445^{* * * *} \\
(0.148) \\
\end{array}$ & $\begin{array}{c}8.384^{* * * *} \\
(0.164) \\
\end{array}$ \\
\hline Observations & 358,000 & 358,000 & 358,000 & 336,000 \\
\hline R-squared & 0.026 & 0.030 & 0.030 & 0.031 \\
\hline Number of Households & & 157,000 & 157,000 & 155,000 \\
\hline Dose Treatment & OLS & HFE & $\begin{array}{c}\text { HFE With } \\
\text { Control for } \\
\text { Parents' Earnings } \\
\text { While a Teenager }\end{array}$ & $\begin{array}{c}\text { HFE with } \\
\text { Controls for } \\
\text { Parents' Earnings } \\
\text { and } \\
\text { Neighborhood } \\
\end{array}$ \\
\hline Voucher & $\begin{array}{c}-0.050 * * * \\
(0.006)\end{array}$ & $\begin{array}{c}0.072 * * * \\
(0.014)\end{array}$ & $\begin{array}{c}0.072 * * * \\
(0.014)\end{array}$ & $\begin{array}{c}0.072 * * * \\
(0.015)\end{array}$ \\
\hline Voucher*Male & $\begin{array}{c}-0.046 * * * \\
(0.010)\end{array}$ & $\begin{array}{c}-0.056 * * * \\
(0.012)\end{array}$ & $\begin{array}{c}-0.056^{* * *} \\
(0.012)\end{array}$ & $\begin{array}{c}-0.050 * * * \\
(0.013)\end{array}$ \\
\hline Public Housing & $\begin{array}{c}-0.079 * * * \\
(0.008)\end{array}$ & $\begin{array}{c}0.067 * * * \\
(0.020)\end{array}$ & $\begin{array}{c}0.068 * * * \\
(0.020)\end{array}$ & $\begin{array}{l}0.039 * \\
(0.021)\end{array}$ \\
\hline Public Housing*Male & $\begin{array}{l}-0.007 \\
(0.013)\end{array}$ & $\begin{array}{l}-0.014 \\
(0.017)\end{array}$ & $\begin{array}{l}-0.015 \\
(0.017)\end{array}$ & $\begin{array}{l}0.030 * \\
(0.018)\end{array}$ \\
\hline Constant & $\begin{array}{c}8.865^{* * *} \\
(0.022)\end{array}$ & $\begin{array}{c}8.678 * * * \\
(0.029)\end{array}$ & $\begin{array}{c}8.427 * * * \\
(0.148)\end{array}$ & $\begin{array}{c}8.358 * * * \\
(0.165)\end{array}$ \\
\hline Observations & 358,000 & 358,000 & 358,000 & 336,000 \\
\hline R-squared & 0.025 & 0.030 & 0.030 & 0.031 \\
\hline Number of Households & & 157,000 & 157,000 & 155,000 \\
\hline
\end{tabular}

Source and Notes: See Table 3. 
Table 6. The Effect of Teenage Residence in HUD-Subsidized Housing on Total 2008-2010 Earnings, Hispanic Households

\begin{tabular}{|c|c|c|c|c|}
\hline Dummy Treatment & OLS & HFE & $\begin{array}{c}\text { HFE With } \\
\text { Control for } \\
\text { Parents' } \\
\text { Earnings While } \\
\text { a Teenager }\end{array}$ & $\begin{array}{l}\text { HFE with } \\
\text { Controls for } \\
\text { Parents' } \\
\text { Earnings and } \\
\text { Neighborhood }\end{array}$ \\
\hline Voucher & $\begin{array}{c}-0.982 * * * \\
(0.040)\end{array}$ & $\begin{array}{c}-0.164 * * \\
(0.078)\end{array}$ & $\begin{array}{c}-0.178 * * \\
(0.078)\end{array}$ & $\begin{array}{l}-0.159 * \\
(0.082)\end{array}$ \\
\hline Voucher*Male & $\begin{array}{l}-0.064 \\
(0.058)\end{array}$ & $\begin{array}{l}-0.003 \\
(0.066)\end{array}$ & $\begin{array}{c}0.023 \\
(0.066)\end{array}$ & $\begin{array}{c}0.011 \\
(0.069)\end{array}$ \\
\hline Public Housing & $\begin{array}{c}-0.905^{* * *} \\
(0.054)\end{array}$ & $\begin{array}{l}-0.018 \\
(0.101)\end{array}$ & $\begin{array}{l}-0.028 \\
(0.101)\end{array}$ & $\begin{array}{c}0.008 \\
(0.107)\end{array}$ \\
\hline Public Housing*Male & $\begin{array}{c}0.126 \\
(0.078)\end{array}$ & $\begin{array}{c}0.073 \\
(0.092)\end{array}$ & $\begin{array}{c}0.095 \\
(0.092)\end{array}$ & $\begin{array}{l}-0.017 \\
(0.099)\end{array}$ \\
\hline Constant & $\begin{array}{c}9.243 * * * \\
(0.017) \\
\end{array}$ & $\begin{array}{c}9.029 * * * \\
(0.031) \\
\end{array}$ & $\begin{array}{c}9.260 * * * \\
(0.159)\end{array}$ & $\begin{array}{c}9.504^{* * *} \\
(0.174)\end{array}$ \\
\hline Observations & 301,000 & 301,000 & 301,000 & 280,000 \\
\hline R-squared & 0.009 & 0.002 & 0.002 & 0.003 \\
\hline Number of Households & & 135,000 & 135,000 & 132,000 \\
\hline Dose Treatment & OLS & HFE & $\begin{array}{c}\text { HFE With } \\
\text { Control for } \\
\text { Parents' } \\
\text { Earnings While } \\
\text { a Teenager }\end{array}$ & $\begin{array}{l}\text { HFE with } \\
\text { Controls for } \\
\text { Parents' } \\
\text { Earnings and } \\
\text { Neighborhood }\end{array}$ \\
\hline Voucher & $\begin{array}{c}-0.235^{* * *} \\
(0.011)\end{array}$ & $\begin{array}{l}-0.010 \\
(0.022)\end{array}$ & $\begin{array}{l}-0.014 \\
(0.022)\end{array}$ & $\begin{array}{c}-0.016 \\
(0.023)\end{array}$ \\
\hline Voucher*Male & $\begin{array}{l}-0.021 \\
(0.016)\end{array}$ & $\begin{array}{c}-0.004 \\
(0.018)\end{array}$ & $\begin{array}{c}0.003 \\
(0.018)\end{array}$ & $\begin{array}{l}-0.001 \\
(0.018)\end{array}$ \\
\hline Public Housing & $\begin{array}{c}-0.235^{* * *} \\
(0.015)\end{array}$ & $\begin{array}{c}0.007 \\
(0.032)\end{array}$ & $\begin{array}{c}0.004 \\
(0.032)\end{array}$ & $\begin{array}{c}0.007 \\
(0.034)\end{array}$ \\
\hline Public Housing*Male & $\begin{array}{c}0.027 \\
(0.022)\end{array}$ & $\begin{array}{c}0.007 \\
(0.026)\end{array}$ & $\begin{array}{l}0.014 \\
0.026\end{array}$ & $\begin{array}{l}-0.016 \\
(0.028)\end{array}$ \\
\hline Constant & $\begin{array}{c}9.228 * * * \\
(0.017) \\
\end{array}$ & $\begin{array}{c}9.014 * * * \\
(0.031) \\
\end{array}$ & $\begin{array}{c}9.243^{* * * *} \\
(0.158) \\
\end{array}$ & $\begin{array}{c}9.494 * * * \\
(0.174) \\
\end{array}$ \\
\hline Observations & 301,000 & 301,000 & 301,000 & 280,000 \\
\hline R-squared & 0.008 & 0.002 & 0.002 & 0.003 \\
\hline Number of Households & & 135,000 & 135,000 & 132,000 \\
\hline
\end{tabular}

Source and Notes: See Table 3. 
Table 7. Summary of the Effect of Teenage Residence in HUD-Subsidized Housing on Total 2008-2010 Earnings, by Gender, Household Fixed Effects Specification

\begin{tabular}{|c|c|c|c|c|c|c|}
\hline & \multicolumn{3}{|c|}{ Dummy } & \multicolumn{3}{|c|}{ Dose } \\
\hline & $\begin{array}{l}\text { Housing } \\
\text { Vouchers } \\
\text { Treatment } \\
\text { Effect } \\
\end{array}$ & $\begin{array}{l}\text { Public } \\
\text { Housing } \\
\text { Treatment } \\
\text { Effect } \\
\end{array}$ & $\begin{array}{l}\text { P-Value: } \\
\text { Treatment } \\
\text { Effects } \\
\text { Are Equal }\end{array}$ & $\begin{array}{l}\text { Housing } \\
\text { Vouchers } \\
\text { Treatment } \\
\text { Effect } \\
\end{array}$ & $\begin{array}{c}\text { Public } \\
\text { Housing } \\
\text { Treatment } \\
\text { Effect }\end{array}$ & $\begin{array}{l}\text { P-Value: } \\
\text { Treatment } \\
\text { Effects } \\
\text { Are Equal }\end{array}$ \\
\hline \multicolumn{7}{|c|}{ All Households } \\
\hline \multirow[t]{2}{*}{ Females } & 0.010 & 0.039 & 0.599 & 0.016 & 0.024 & 0.654 \\
\hline & $(0.034)$ & $(0.044)$ & & $(0.010)$ & $(0.015)$ & \\
\hline \multirow[t]{2}{*}{ Males } & $-0.080 * *$ & 0.049 & $0.031^{* *}$ & -0.006 & $0.034 * *$ & $0.027 * *$ \\
\hline & $(0.036)$ & $(0.049)$ & & $(0.010)$ & $(0.016)$ & \\
\hline Observations & $1,801,000$ & $1,801,000$ & & $1,801,000$ & $1,801,000$ & \\
\hline \multicolumn{7}{|c|}{ White Households } \\
\hline \multirow[t]{2}{*}{ Females } & $-0.108 *$ & $-0.237 * * *$ & 0.217 & -0.011 & -0.048 & 0.348 \\
\hline & $(0.060)$ & $(0.085)$ & & $(0.020)$ & $(0.034)$ & \\
\hline \multirow[t]{2}{*}{ Males } & 0.063 & $0.167^{*}$ & 0.361 & 0.021 & 0.049 & 0.491 \\
\hline & $(0.063)$ & $(0.095)$ & & $(0.020)$ & $(0.036)$ & \\
\hline Observations & $1,027,000$ & $1,027,000$ & & $1,027,000$ & $1,027,000$ & \\
\hline \multicolumn{7}{|c|}{ Black Households } \\
\hline \multirow[t]{2}{*}{ Females } & $0.207 * * *$ & $0.179 * * *$ & 0.724 & $0.072 * * *$ & $0.067 * * *$ & 0.837 \\
\hline & $(0.051)$ & $(0.060)$ & & $(0.014)$ & $(0.020)$ & \\
\hline \multirow[t]{2}{*}{ Males } & -0.075 & 0.031 & 0.218 & 0.016 & $0.054 * *$ & 0.133 \\
\hline & $(0.054)$ & $(0.068)$ & & $(0.015)$ & $(0.021)$ & \\
\hline Observations & 358,000 & 358,000 & & 358,000 & 358,000 & \\
\hline \multicolumn{7}{|c|}{ Hispanic Households } \\
\hline \multirow[t]{2}{*}{ Females } & $-0.164 * *$ & -0.018 & 0.248 & -0.010 & 0.007 & 0.644 \\
\hline & $(0.078)$ & $(0.101)$ & & $(0.022)$ & $(0.032)$ & \\
\hline \multirow[t]{2}{*}{ Males } & $-0.168 * *$ & 0.055 & $0.091 *$ & -0.014 & 0.015 & 0.452 \\
\hline & $(0.080)$ & $(0.106)$ & & $(0.022)$ & $(0.033)$ & \\
\hline Observations & 301,000 & 301,000 & & 301,000 & 301,000 & \\
\hline \multicolumn{7}{|c|}{$\begin{array}{l}\text { SOURCE: Tables 3-6. } \\
\text { Notes: All panels present the estimated average partial effect (APE) of each type of subsidized housing (Vouchers or Public) on the } \\
\text { inverse hyperbolic sine of adult earnings, separately for males and females. In all cases the APE is estimated at the mean of all of the } \\
\text { other control variables. Estimates do not control for parents' earnings as a teenager or average block group percent poverty as a } \\
\text { teenager. Columns } 3 \text { and } 6 \text { present the p-value from a test of equality of the APEs across subsidized housing type (Vouchers or Public) } \\
\text { for each sex. Observations rounded to the nearest thousand. Standard errors in parentheses. }{ }^{* * *} p<0.01,{ }^{* *} p<0.05,{ }^{*} p<0.1\end{array}$} \\
\hline
\end{tabular}




\section{Appendix A: Major U.S. Subsidized Rental Housing Programs}

There is a wide variety of subsidized housing programs. Table A-1 presents the major programs and the number of units subsidized.

Beginning in the 1930s, the U.S. government built public housing projects, and for decades, the program continued to be the primary means of federal assistance for rental housing. The Housing Act of 1949 introduced income limits and “Fair Market Rents” along with subsidies that would incentivize private development of low-cost housing and were further expanded in the late 1960s. In the 1980s, production was drastically reduced as housing assistance became a more decentralized effort, and no federal public housing has been built since 1981. A "regime change” in the mid-1980s additionally introduced even stricter requirements to focus assistance on the poorest households. There were about 1.4 million public housing units in 1990, falling to just under 1.3 million in 2000, and about 1.1 million in 2008. The reduction in these numbers reflects demolition of the worst-performing projects starting in the 1990s. In these cases, under the HOPE VI program, tenants are typically given housing vouchers to find housing elsewhere (Popkin et al. 2004). Today, over 3,000 Public Housing Authorities administer public housing projects, mostly for the very poor and typically neighborhoods that are predominantly lowincome.

The Housing Choice Voucher Program (HCVP) provides direct rental assistance to housing tenants through vouchers. The Section 8 New Construction and Substantial Rehabilitation project-based subsidy program assists owners of housing units so that they may charge affordable rents; it accounted for almost 900,000 units in 2000. Note that these households are much smaller and live in smaller dwellings than their counterparts in residing public housing or receiving vouchers. This reflects in part the large share of elderly occupants.

While Section 8 subsidized housing began as project-based housing subsidy in 1974 and at that time was based on new construction, now much of the housing historically referred to as Section 8 housing is found in the tenant-based HCVP program. HCVP has developed more recently and is solely a demand-side, tenant-based subsidy program. Stemming from the ambitious Experimental Housing Allowance Program of the 1970s (see Friedman and Weinberg 1982, 1983) this program brings a different perspective to housing policy by separating itself from new production. Rather than choosing among specific subsidized housing locations, 
voucher recipients may live in any structurally adequate rental housing in a specified rent and size range, with the Federal subsidy making the unit affordable. Public Housing Authorities may to allocate up to 20 percent of their HCVP funds for project-based vouchers that are tied to specific private housing developments, rather than to the tenant. Tenant vouchers can be used by those wishing to live in Low Income Housing Tax Credit housing (described below) and thus there is the potential for multiple types of subsidies for a given unit. This program provides anonymity and a choice of locations, although landlord willingness to participate limits its extent. There were about 1.1 million voucher households in 1990, growing dramatically to 1.8 million in 2000, and continuing to grow. Currently, over 30 percent of U.S. subsidized housing is provided by vouchers.

The Low Income Housing Tax Credit (LIHTC) program began with the 1986 Tax Reform Act, and was expanded by 40 percent in 2001. Unlike the “deep subsidies” provided by the other three programs discussed here, LIHTC provides "shallow subsidies" in that no ongoing operating costs are covered by the government. In this program, the U.S. government (through the Internal Revenue Service), provides tax credits to for-profit and non-profit developers to build income-restricted housing. In 1990, there were about 140,000 units, growing to almost 1 million in 2000, and growing further to almost 1.7 million units in 2008. While LIHTC housing has significant income limits for eligibility, this program does not provide housing for the very poor. Another concern raised about the LIHTC program is that it may crowd out nearby private investment in affordable rental housing, as Eriksen and Rosenthal (2010) find. 
Table A-1. Total Subsidized Rental Dwelling Units, 1990, 2000, and 2008

\begin{tabular}{|c|c|c|c|}
\hline & 1990 & 2000 & 2008 \\
\hline Public Housing & $1,404,870$ & $1,282,099$ & $1,155,557$ \\
\hline $\begin{array}{l}\text { Housing Choice Vouchers (previously Voucher- } \\
\text { supported housing--Tenant-Based) }\end{array}$ & $1,137,244$ & $1,817,360$ & $2,209,675$ \\
\hline $\begin{array}{l}\text { Voucher-supported housing--Moderate } \\
\text { Rehabilitation }\end{array}$ & $*$ & 111,392 & 27,067 \\
\hline $\begin{array}{l}\text { Voucher-supported housing--New Construction } \\
\text { or Substantial Rehabilitation }\end{array}$ & 822,962 & 877,830 & $1,116,250$ \\
\hline $\begin{array}{l}\text { Federal Housing Authority (FHA) Section } 236 \\
\text { Projects }\end{array}$ & 530,625 & 440,329 & 225,167 \\
\hline $\begin{array}{l}\text { All Other Multifamily Assisted Properties with } \\
\text { FHA Insurance or Department of Housing and } \\
\text { Urban Development (HUD) Subsidy }\end{array}$ & $*$ & 352,337 & 329,355 \\
\hline All HUD-subsidized units & $4,515,000$ & $4,881,081$ & $5,063,071$ \\
\hline Low Income Housing Tax Credit (LIHTC) & 139,094 & 945,347 & $1,672,239$ \\
\hline
\end{tabular}

SOURCE: Olsen (2003) for 1990; HUDUSER, U.S. Department of Housing and Urban Development (HUD), for 2000 and 2008.

* Data not readily available. 
Appendix B: Characteristics of Data from HUD's Public and Indian Housing Information Center (PIC) (SOURCE: Authors' tabulations)

Table B1: Rate of Occupants Having Non-missing Variables in 2000 HUD-PIC File

\begin{tabular}{|lc|}
\hline Variable & Percentage \\
\hline Master Address File ID & $75.0 \%$ \\
Protected Identification & \\
Key & $97.8 \%$ \\
Date of Birth & $99.6 \%$ \\
Gender & $99.6 \%$ \\
Race & $98.3 \%$ \\
Ethnicity & $98.3 \%$ \\
Person type & $99.6 \%$ \\
\hline
\end{tabular}

Table B2: Person Type of Occupants in 2000 HUD-PIC File

\begin{tabular}{|lc|}
\hline Person Type & Percentage \\
\hline Head of Household/ & \\
Co-Head of Household/Spouse & $44.8 \%$ \\
Youth & $47.2 \%$ \\
Other & $8.0 \%$ \\
\hline
\end{tabular}

Table B3: Age and Gender of Teenagers Aged 13-18 in 2000 HUD-PIC File

\begin{tabular}{|c|c|c|c|}
\hline AGE & $\begin{array}{c}\text { Male and } \\
\text { Female }\end{array}$ & Male & Female \\
\hline 13 & $19.0 \%$ & $19.2 \%$ & $18.9 \%$ \\
\hline 14 & $17.8 \%$ & $17.9 \%$ & $17.7 \%$ \\
\hline 15 & $17.2 \%$ & $17.3 \%$ & $17.2 \%$ \\
\hline 16 & $16.2 \%$ & $16.2 \%$ & $16.1 \%$ \\
\hline 17 & $15.2 \%$ & $15.1 \%$ & $15.3 \%$ \\
\hline 18 & $14.6 \%$ & $14.3 \%$ & $14.8 \%$ \\
\hline
\end{tabular}

Table B4: Race and Ethnicity of Housing Occupants in 2000 HUD-PIC File

\begin{tabular}{|llc|}
\hline & & Percentage \\
\hline \multirow{2}{*}{ Race } & White & $46.6 \%$ \\
& Black & $49.2 \%$ \\
& Other & $4.2 \%$ \\
\hline \multirow{2}{*}{ Ethnicity } & Hispanic & $19.8 \%$ \\
& Non-Hispanic & $80.2 \%$ \\
\hline
\end{tabular}

